\title{
Cost of premature mortality attributable to smoking in the Middle East and North Africa
}

Mouaddh Nagi, ${ }^{1,2}$ Arthorn Riewpaiboon ${ }^{3}$ and Montarat Thavorncharoensap ${ }^{3}$

${ }^{1}$ Master of Science Program in Social, Economic, and Administrative Pharmacy, Faculty of Pharmacy, Mahidol University, Bangkok, Thailand. ${ }^{2}$ Faculty of Medical Science, Aljanad University, Taiz, Yemen. ${ }^{3}$ Social and Administrative Pharmacy Excellence Research Unit, Department of Pharmacy, Faculty of Pharmacy, Mahidol University, Bangkok, Thailand. (Correspondence to: M. Thavorncharoensap: montarat.tha@mahidol.ac.th).

\begin{abstract}
Background: Tobacco smoking is a leading cause of premature mortality, incurring substantial economic costs.

Aims: To estimate the rate and cost of premature mortality attributable to smoking in the 24 Middle East and North Africa (MENA) countries in 2015 .

Methods: Smoking attributable fractions were estimated. Twenty-four smoking-related diseases were included in the analysis. For each country, the total number of deaths by disease, age, and gender among individuals aged $\geq 15$ years were derived from a World Health Organization database. Human capital approach was used in calculating cost of premature mortality.

Results: Smoking was responsible for 465285 deaths in MENA countries, resulting in 7122706 years of potential life lost, or an average of 15.23 years lost per smoking-related death. Of the total 465285 smoking-related deaths, 412415 (88.6\%) occurred in men, accounting for $37 \%$ of all deaths from the diseases considered in this analysis among men. The total mortality cost attributable to smoking was estimated at US\$29.7 billion in 2015 (0.76\% of MENA's gross domestic product). Turkey was the country most affected by the tobacco epidemic, representing $41 \%$ of smoking-related mortality cost in the whole region, followed by Saudi Arabia (8.76\%) and Egypt (7.88\%).

Conclusion: Smoking is an important preventable cause of premature mortality in MENA countries. Substantial decline in smoking-attributable deaths and significant economic cost saving can be achieved in this region through more effective tobacco control policies.

Keywords: cost, MENA, premature mortality, smoking attributable fraction, smoking

Citation: Nagi M; Riewpaiboon A; Thavorncharoensap M. Cost of premature mortality attributable to smoking in the Middle East and North Africa. East Mediterr Health J. 2021;27(10):974-983. https://doi.org/10.26719/emhj.21.028

Received: 26/08/20; accepted: 01/03/21

Copyright (C) World Health Organization (WHO) 2021. Open Access. Some rights reserved. This work is available under the CC BY-NC-SA 3.0 IGO license (https://creativecommons.org/licenses/by-nc-sa/3.o/igo)
\end{abstract}

\section{Introduction}

Tobacco smoking has been established as an important risk factor for many types of diseases, such as cardiovascular diseases, cancer, chronic obstructive pulmonary disease (COPD), lower and upper respiratory tract infections, and asthma (1). Tobacco smoking is recognized as the leading preventable cause of death (1), and was responsible for $\sim 6.4$ million deaths ( $11.5 \%$ of global deaths) in 2015, ranking it among the 5 leading risk factors for disability-adjusted life years loss in 109 countries (2).

The economic impact of tobacco smoking is substantial, especially in terms of premature mortality. The total economic cost of smoking was estimated at US 1436 billion, which accounted for $1.8 \%$ of the world's annual gross domestic product (GDP) in 2012 (3). Globally, the cost of premature mortality due to smoking was estimated at US\$ 657 billion in 2012, representing 51\% of the total cost of smoking (3).

The Middle East and North Africa (MENA) is a diverse region consisting of high-, middle- and low-income countries. The population of the MENA region is at least 750 million or $10 \%$ of the world's population (4). The definition of MENA is controversial and variable, with many overlapping regions. In terms of World Health Organization (WHO) regions, most countries in MENA are member states of the Eastern Mediterranean Region, except for Algeria and Mauritania, which are members of the African Region and Turkey, which belongs to the European Region.

Despite the decline in smoking prevalence in several high-income countries, the prevalence in many MENA countries remains high and is increasing (5). The prevalence of smoking in the MENA Region ranged from an average of 50\% among men and 5\% among women. Surprisingly, > 50\% of young people have initiated smoking before age 10 years (5). Lack of political commitment to tobacco control and tobacco industry tactics are considered the major challenges in reducing the tobacco epidemic in the MENA Region.

Due to population ageing and marked demographic and socioeconomic transitions, several diseases currently pose a major challenge to healthcare systems in the MENA Region. In 2012, > 800000 new cancer cases and 360000 cancer deaths were estimated (6). Furthermore, cancer mortality in the MENA Region is expected to increase 
dramatically with the rate of $181 \%$ over the next 15 years (7). In addition, cardiovascular diseases are the leading cause of death in the WHO Eastern Mediterranean Region, causing 1.4 million deaths (34.1\% of all deaths in the Region) in 2015 (8). Lower respiratory tract infections (LRTIs) resulted in 191114 deaths and 11 million disabilityadjusted life years in the Eastern Mediterranean Region, which is higher than global rates, making it the third leading cause of deaths ( 9 ).

The objectives of this study were to estimate the rate of premature mortality, years of potential life lost (YPLL), and cost of premature mortality attributable to smoking in MENA countries in 2015. Such information clearly depicts the number of deaths that could be prevented as well as the cost that could be saved by more effective tobacco control policies. The findings can provide clear economic evidence for governments in the MENA Region to respond effectively to the tobacco epidemic by strengthening their existing tobacco control policies and regulations.

\section{Methods}

\section{Study design}

This was a descriptive, prevalence-based, cost-of-illness study. Smoking-attributable fractions (SAFs) were calculated to estimate the number of premature mortality attributable to smoking. To estimate the cost of premature mortality attributable to smoking (10), we used the human capital method (HCM). HCM is commonly used to estimate indirect cost due to productivity loss. Under this method, the cost of productivity loss was estimated by multiplying the total period of absence from work due to ill health, disability or premature mortality by the wage rate of the absent person. For cost of premature mortality, the productivity loss was valued in terms of the present value of expected future earnings throughout the remaining years of life expectancy at time of premature death.

\section{Study settings}

We adopted the widest definition of MENA by including the countries as stated by the World Bank (11) plus Afghanistan and Pakistan. Turkey was also included as it shares many characteristics with the listed countries and is often included in the Middle East. Somalia and Sudan were included according to the definition by The Joint United Nations Programme on HIV/AIDS (UNAIDS) and United Nations Children's Fund (UNICEF) (12), and Mauritania was included according to the definition by United Nations High Commissioner for Refugees (UNHCR) (13). Thus, our analysis extended to 24 countries (Table 1). Palestine was not included in this analysis due to the unavailability of relevant data.

\section{Smoking-associated diseases}

Sixteen types of cancer that showed a causal relationship with tobacco consumption in large epidemiological studies were included in this analysis $(1,14,15)$. These includ- ed malignancies of the lip and oral cavity, nasal cavity, pharynx, oesophagus, stomach, colorectum, liver (not including cancers secondary to hepatitis $\mathrm{B}$, hepatitis $\mathrm{C}$ or alcohol consumption), pancreas, lungs and trachea, breast, uterine cervix, ovaries, kidneys, urinary bladder and larynx, and leukaemia (1). Four cardiovascular diseases [ischaemic heart disease (IHD), rheumatic heart disease, hypertensive heart disease, and stroke] along with 3 respiratory diseases (asthma, LRTI and COPD) and diabetes mellitus were included in the analysis due to a causal relationship between smoking and their etiology (1).

\section{Estimation of SAF}

SAF for each disease (i) was calculated by the following formula (10):

$$
\operatorname{SAF}_{i}(\%)=\frac{P\left(R R_{i}-1\right)}{1+P\left(R R_{i}-1\right)} \times 100
$$

where $P$ is the prevalence of current smoking of any tobacco product for each country (aged $\geq 15$ years), and $R R_{i}$ is relative risk of smoking for disease $i(1,2,-24)$ included in this analysis.

Prevalence of current smoking (cigarettes, cigars, water pipe, etc.) among individuals aged $\geq 15$ years was obtained from various sources (16-21) (Table 1). Prevalence in 2010 or a few years before was adopted for estimating SAF, to capture the accumulated hazard of smoking. This is because incidences of diseases observed in 2015 reflect past exposure to smoking. If we were unable to find the prevalence rate for 2010, we used the closest available estimates.

The RRs of tobacco-smoking-related diseases were obtained from recent, well-designed meta-analyses $(1,14,15,22-24)$ (Table 2). It should be noted that LRTI is a term that usually includes pneumonia and bronchitis. In this study, RR for bronchitis (24) was used to represent LRTI.

\section{Estimation of mortality attributable to smoking (MAS)}

The total numbers of deaths in 2015 (aged $\geq 15$ years) from each disease by sex and age were derived from a WHO database (25) and multiplied by the corresponding SAF to estimate the number of premature mortality attributable to smoking for disease $i\left(\mathrm{MAS}_{\mathrm{i}}\right)$ in 2015.

\section{Estimation of mortality cost attributable to smoking (MCAS)}

Based on HCM, premature mortality cost attributable to smoking for disease $i$ according to sex $k\left(M_{C A S}\right)$ was calculated as follows:

where

$$
\operatorname{MCAS}_{\mathrm{ik}}=\sum_{j=1}^{n}\left(\mathrm{MAS}_{\mathrm{ijk}} \times \operatorname{PVLE}_{\mathrm{jk}}\right)
$$

$$
\mathrm{MAS}_{i j \mathrm{k}}=\mathrm{SAF}_{i k} \times \text { Tdeath }_{i j \mathrm{k}}
$$

$\mathrm{SAF}_{i \mathrm{k}}=$ smoking attributable fraction of death from disease $i$ and sex $k$ ( 1 or 2$)$ 


\begin{tabular}{|c|c|c|c|c|c|}
\hline \multirow[t]{2}{*}{ Country } & \multirow{2}{*}{$\begin{array}{c}\text { Population as of } \\
\text { July } 2015 \\
\text { in millions }\end{array}$} & \multirow[t]{2}{*}{$\begin{array}{c}\text { GDP/capita } \\
\text { US\$ in } 2015 \text { (refs) }\end{array}$} & \multicolumn{2}{|c|}{$\begin{array}{l}\text { Prevalence of smoking } \\
(\%)\end{array}$} & \multirow[t]{2}{*}{$\begin{array}{l}\text { Year of prevalence } \\
\text { estimation (refs) }\end{array}$} \\
\hline & & & Male & Female & \\
\hline Afghanistan & 32.5 & $627(27)$ & 22.9 & 2.8 & $2010(20)$ \\
\hline Algeria & 39.7 & $4151(27)$ & 27.0 & 3.0 & $2010(16)$ \\
\hline Bahrain & 1.4 & $24063(27)$ & 35.0 & 6.0 & $2010(16)$ \\
\hline Djibouti & 0.9 & $1788(27)$ & 24.8 & 1.7 & $2017(17)$ \\
\hline Egypt & 91.5 & $3731(27)$ & 42.7 & 0.5 & $2010(16)$ \\
\hline Islamic Republic of Iran & 79 & $4723(27)$ & 22.2 & 1.3 & $2010(16)$ \\
\hline Iraq & 36.4 & $4869(27)$ & 27.0 & 3.0 & $2006(16)$ \\
\hline Jordan & 7.6 & $5506(27)$ & 62.7 & 9.8 & $2010(16,19)$ \\
\hline Kuwait & 3.9 & $27885(27)$ & 42.3 & 4.4 & $2006(16,17)$ \\
\hline Lebanon & 5.9 & $11178(27)$ & 41.6 & 27.5 & $2010(16)$ \\
\hline Libya & 6.3 & $2813(27)$ & 50.0 & 1.0 & $2009(16)$ \\
\hline Mauritania & 4.1 & $1307(27)$ & 38.6 & 4.5 & $2010(16)$ \\
\hline Morocco & 34.4 & $2965(27)$ & 41.7 & 2.0 & $2010(16)$ \\
\hline Oman & 4.5 & $18485(27)$ & 18.0 & 1.0 & $2010(16)$ \\
\hline Pakistan & 189.0 & $1425(27)$ & 37.9 & 3.7 & $2010(16)$ \\
\hline Qatar & 2.2 & $67537(27)$ & 21.3 & 0.6 & $2013(17)$ \\
\hline Saudi Arabia & 31.5 & $21095(27)$ & 25.9 & 2.8 & $2010(16)$ \\
\hline Somalia & 10.8 & $426(28)$ & 19.7 & 2.3 & $2013(20)$ \\
\hline Sudan & 40.2 & $2119(27)$ & 23.8 & 2.1 & $2010(17)$ \\
\hline Syrian Arab Republic & 18.5 & $1821(29)$ & 56.9 & 17.0 & $2006(18,21)$ \\
\hline Tunisia & 11.3 & $3884(27)$ & 65.4 & 1.2 & $2017(17)$ \\
\hline Turkey & 78.7 & $10915(27)$ & 45.9 & 14.6 & $2010(16)$ \\
\hline United Arab Emirates & 9.2 & $37361(27)$ & 36.8 & 1.3 & $2017(17)$ \\
\hline Yemen & 26.8 & $1334(27)$ & 21.0 & 6.0 & $2013(16)$ \\
\hline
\end{tabular}

GDP = gross domestic product; $M E N A=$ Middle East and North Africa.

Tdeath $_{\mathrm{ijk}}=$ total number of deaths (aged $\geq 15$ years) from disease $i$ for age group $j(1,2-5)$ and sex $k$

$\mathrm{PVLE}_{\mathrm{jk}}=$ total discounted present value of lifetime earnings for age group $j$ and sex $k$.

$n=$ the number of age group in the analysis (i.e., 15-29, $30-49,50-59,60-69$, and 70+).

For each country, YPLL was calculated for each age group for all diseases. We used life tables published by WHO for 2015 that provided age-specific death rates by country for men and women to find the remaining life expectancy at the time of death (26).

PVLE was estimated for each sex and age group by combining the annual income per capita, discount rate, and corresponding life expectancy for that age group. GDP per capita during 2015 for each country was derived from the International Monetary fund (IMF) (27), along with World Bank (28), and United Nations (29) and then were used as an annual income rate (Table 1). A discount rate of $3 \%$ was applied in this study.

\section{Ethical approval}

Ethical approval was not required for this study since it did not include human subjects.

\section{Results}

The number of premature deaths, cost, and YPLL attributable to smoking for each disease are presented in Table 3. Of the total 2126379 deaths that occurred from 24 diseases in MENA in 2015, smoking was responsible for 465285 deaths - 412415 for men $(88.6 \%)$ and 52870 for women (11.4\%). This accounted for $22 \%$ (37.2\% among men and 5.2\% among women) of all deaths occurring from the diseases considered in this analysis, resulting in 7122706 YPLL - 6306254 years in men and 816452 years in women. The average years of life lost per each smoking-related death in MENA was 15.23 years. The total MCAS was valued at US\$29 729.7 million. This represents $0.76 \%$ of MENA's total GDP in 2015.

The greatest association was seen between smoking and trachea, bronchus and lung cancer (71.3\%), followed by laryngeal cancer (62.1\%), and pharyngeal cancer (48.2\%) (Table 3). The highest MAS was from IHD (173 351 deaths in men and 19479 in women); stroke (68 920 deaths in men and 10164 in women); COPD (43 135 deaths in men and 6117 in women); and trachea, bronchus and lung cancers (38 335 deaths in men and 3500 in women). The top 3 diseases attributable to MCAS were IHD (US\$ 11430.4 million), followed by lung cancer (US\$ 4572.2 million) 


\begin{tabular}{|c|c|c|c|}
\hline \multirow[t]{2}{*}{ Disease (refs) } & \multicolumn{3}{|c|}{ Relative risk } \\
\hline & Male & Female & All \\
\hline Bladder cancer (14) & 2.77 & 2.77 & 2.77 \\
\hline Breast cancer (1) & 4.16 & 1.06 & NA \\
\hline Uterine cervix cancer (14) & NA & 1.83 & NA \\
\hline Colorectal cancers (14) & 1.13 & 1.40 & 1.20 \\
\hline Oesophagus cancer (14) & 2.50 & 2.50 & 2.50 \\
\hline Kidney cancer (14) & 1.52 & 1.52 & 1.52 \\
\hline Larynx cancer (14) & 6.98 & 6.98 & 6.98 \\
\hline Lip and oral cavity cancer (14) & 3.43 & 3.43 & 3.43 \\
\hline Liver cancer (14) & 1.56 & 1.56 & 1.56 \\
\hline Myeloid leukaemia (1) & 1.86 & 1.13 & NA \\
\hline Nasal and sinus cancers (14) & 1.95 & 1.95 & 1.95 \\
\hline Ovary cancer (14) & NA & 2.07 & NA \\
\hline Pancreas cancer (14) & 1.70 & 1.70 & 1.70 \\
\hline Pharynx cancer (14) & 6.76 & 6.76 & 6.76 \\
\hline Stomach cancer (14) & 1.74 & 1.45 & 1.64 \\
\hline Trachea, bronchus, lung cancers (15) & 10.92 & 10.92 & 10.92 \\
\hline Diabetes mellitus (23) & 1.89 & 1.89 & 1.89 \\
\hline Hypertensive heart disease (24) & 1.96 & 2.12 & NA \\
\hline Ischemic heart disease (1) & 2.71 & 3.01 & NA \\
\hline Rheumatic heart disease (1) & 2.17 & 2.01 & NA \\
\hline Stroke (1) & 2.47 & 2.15 & NA \\
\hline Asthma (15) & 1.61 & 1.61 & 1.61 \\
\hline Chronic obstructive pulmonary disease (15) & 4.01 & 4.01 & 4.01 \\
\hline Lower respiratory tract infection (22) & 3.41 & 3.41 & 3.41 \\
\hline
\end{tabular}

and stroke (US\$ 4345.8 million). In terms of YPLL, IHD resulted in the largest YPLL (2 841554 ) followed by stroke (1 145 540) and lung cancer (789 489).

Table 4 presents the total number of premature deaths, cost, and YPLL attributable to smoking for each country. The highest SAF was observed in Lebanon and Turkey (33\%) followed by Jordan (32\%), Syrian Arab Republic (31\%), United Arab Emirates (UAE) (30\%), and Kuwait and Tunisia (29\%). The highest MAS was found in Pakistan (134 130), followed by Turkey (87 173), and Egypt $(55,606)$. The highest MCAS was found in Turkey (approximately US\$ 12.2 billion) which accounted for $\sim 41 \%$ of total MCAS in MENA, followed by Saudi Arabia (approximately US\$2.6 billion), Egypt (approximately US\$2.3 billion), Pakistan (approximately US\$2.3 billion), and UAE (approximately US $\$ 1.7$ billion). The costs incurred by these 5 countries accounted for $71 \%$ of total MCAS in MENA in 2015. MCAS incurred by men was 6 times greater than incurred by women. MCAS accounted for $1.85 \%$ of GDP in Lebanon, $1.68 \%$ in Turkey and $1.32 \%$ in Tunisia.

\section{Discussion}

The findings of this study found that smoking was responsible for 465285 deaths, resulting in 7.12 million
YPLL in the MENA Region during 2015. This accounted for $22 \%$ of all deaths from 24 diseases in the Region. This estimation is in line, but slightly higher, with a recent study in the United States of America, which found that $\sim 18 \%$ of deaths were attributable to smoking (30). In contrast to that study, which found that SAF in men was higher in women (20.6\% vs $15.1 \%)$, but similar to a study in the Association of Southeast Asian Nation (ASEAN) countries (31), we found that SAF among men was higher than in women (37.2\% vs $5.2 \%$ ). This could be explained by the low prevalence of smoking among women in MENA and ASEAN countries.

In our study, the SAF for all cancer types was estimated at $24.5 \%$, which is comparable to the global estimate of $22 \%(36)$ but lower than that in Asian countries (30.5\%) (31). This is probably due to the higher prevalence of smoking in ASEAN countries. When comparing across diseases, similar to the global estimate (32), we found that the highest SAF was in lung cancer (71\%). We found that SAFs for IHD and stroke were estimated at $22.2 \%$ and $18.8 \%$, respectively. These estimates are higher than the global estimates, which found that $\sim 12 \%$ and $\sim 7 \%$ of IHD and stroke was attributable to smoking (32). This is possibly due to the different sources of RRs used in the SAF calculation. More updated RRs were used in our study. 


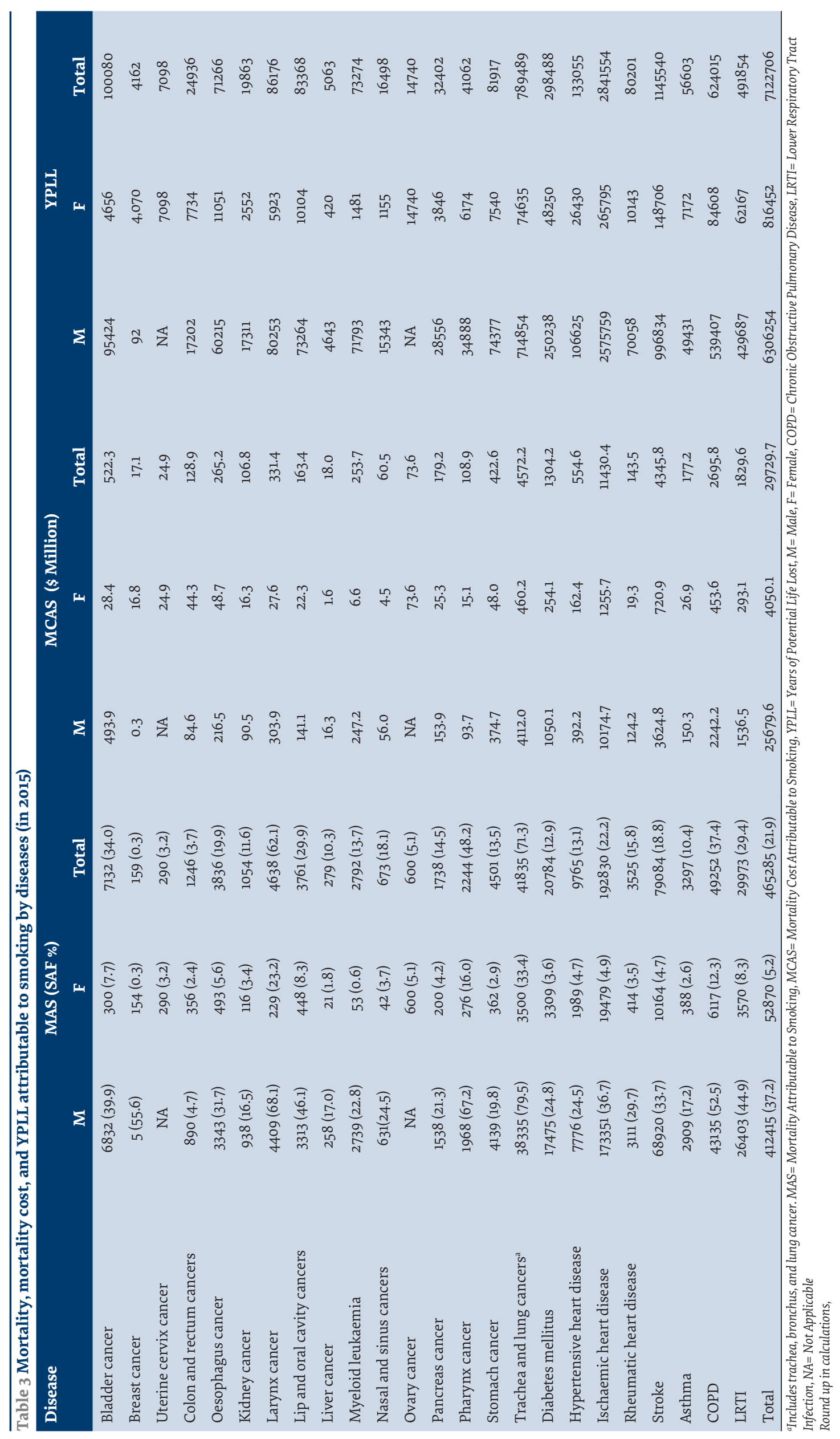




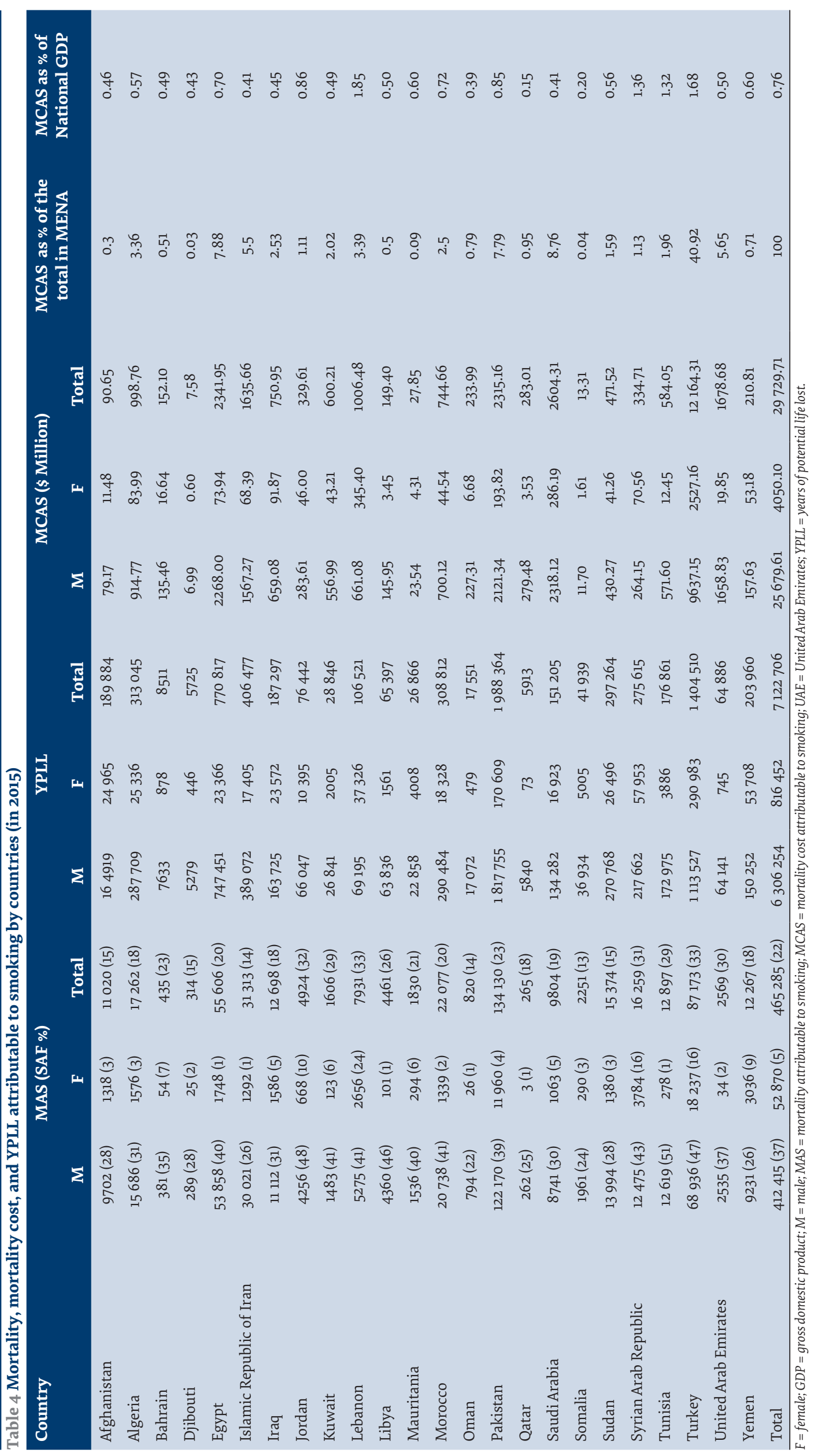


This could also be because death from cardiovascular diseases was more likely to occur among adults aged 30-44 years, and that age group is large in MENA countries. Similarly, SAF of LRTIs in the MENA Region was $29 \%$, which is higher than global estimates of $12 \%$ (32). Additionally, the MAS, MCAS and YPLL from IHD and stroke were high in the MENA Region, not only because of the high SAFs but also the high absolute mortality for IHD and stroke.

In our study, MCAS in the MENA Region was estimated at US\$29.7 billion, which represented $0.76 \%$ of GDP in 2015. This is lower than the global estimates, in which mortality costs were US\$657 billion (2012 value), representing $\sim 0.90 \%$ of global GDP (3), but higher than in China, where mortality costs were US\$22 billion and represented $0.50 \%$ of national GDP (33). If the definition of MENA by the World Bank (exclude Afghanistan, Pakistan, Mauritania, Turkey, Somalia, and Sudan) was adopted, the total cost was equal to US\$14.65 billion.

MAS varied by country due to the differences in population size, background risk of diseases, and prevalence of smoking in each country. Similarly, MCAS also varied by country due to the differences in life expectancy and income rates. We found that SAF was highest in Lebanon and Turkey (33\%), Jordan (32\%) and Syrian Arab Republic (31\%). The lowest SAFs were found in Somalia (13\%), Oman and Islamic Republic of Iran (14\%). This can be explained by the variation in the prevalence of smoking in each country. However, we found that MCAS was highest in Turkey (41\% of MCAS in MENA Region), Saudi Arabia and Egypt. It should be noted that not only MAS but also income contributed to the highest MCAS. The income of the countries in the MENA Region varied widely. In terms of YPLL, life expectancy in the MENA Region was shorter than in other parts of the world due to long-lasting conflicts and natural disasters, which cause substantial increases in death rates and shorter lifespan estimations. This could have led to the low YPLL estimation in our study. A similar impact was found for MCAS, which might be lower estimates when compared to other parts of the world where life expectancy is longer.

It should be noted that our analysis included mortality in the population aged $\geq 15$ years. The reason for this was that $\sim 50 \%$ of smokers in the MENA Region started smoking before age 10 years (5) due to the ease of access to tobacco products and lack of legislation to prohibit smoking before adulthood.

In this study, information on GDP per capita was derived from the IMF. Compared to the World Bank data, most of the estimates were similar (difference is less than $\pm 10 \%$ ). Nevertheless, it should be noted that IMF estimates were slightly lower for Djibouti, Libya and Yemen but higher for Oman and Jordan.

Although this study was the first attempt to estimate MAS, MCAS and YPLL in the MENA Region, the estimates might have some limitations, which should be noted. First, this study did not incorporate smoking intensity and former smokers into SAF estimation due to the unavailability of such information. Second, this analysis included only deaths caused by active smoking and not those caused by second-hand smoking exposure. Therefore, it might have underestimated the number of deaths caused by tobacco use. Third, owing to data scarcity, the RRs used to calculate SAF were mainly specific to cigarette smoking. This could have underestimated the final results because previous evidence indicates that water pipe smoking results in greater nicotine yield and other toxicants, and may result in greater harm than cigarette smoking (34). Additionally, RRs used in this study were based on international records and depended on studies carried out outside the MENA Region in countries with different smoking patterns and profiles. Fourth, although our estimates were based on 24 diseases currently established by the US Surgeon General Report as caused by smoking, it was recently found that smoking is significantly associated with other diseases as well (35). Fifth, this cost estimation was only based on premature mortality using human capital approach which in reality undervalues mortality costs for housewives, self-employed personnel, children, and any workforce outside the formal sector. Additionally, HCM undervalues mortality costs in settings where labour market imperfections exist as the official income does not reflect employees' true opportunity cost of time, especially in developing countries. Furthermore, the direct health expenditure attributable to tobacco use was not estimated as data were scarce to estimate the health costs of treating tobacco-related diseases. Also, productivity loss such as disability, absenteeism and presenteeism were not included. It should also be noted that in this estimation, we did not apply income growth in calculating present value of lifetime earnings as the fluctuation of income in MENA countries may have resulted in a biased estimation of income growth. Nevertheless, income growth should be taken into account when the reliable data are available.

\section{Conclusion}

Smoking is a leading preventable risk factor for mortality in MENA countries, resulting in 465286 deaths or accounting for $22 \%$ of total deaths from 24 diseases in 2015 . The cost of premature mortality attributable to smoking in the region is substantial. This analysis suggests that dramatic declines in smoking-attributable deaths, increase in life-years saved, and significant reduction in mortality costs can be achieved by reducing smoking prevalence. More effort on smoking control should be a policy priority and further efforts are needed towards the implementation and enforcement of effective and comprehensive tobacco control strategies and policies in the MENA Region. 


\section{Acknowledgement}

This work was partially supported by Social, Economic and Administrative Pharmacy graduate program, Faculty of Pharmacy, Mahidol University, Thailand.

Funding: None.

Competing interests: None declared.

\section{Coût de la mortalité prématurée imputable au tabagisme dans la Région Moyen- Orient et Afrique du Nord}

\section{Résumé}

Contexte : Le tabagisme est l'une des principales causes de mortalité prématurée et entraîne des coûts économiques considérables.

Objectifs : Estimer le taux et le coût de la mortalité prématurée attribuable au tabagisme dans les 24 pays de la Région Moyen-Orient et Afrique du Nord en 2015.

Méthodes: Les fractions attribuables au tabagisme ont été estimées. Vingt-quatre maladies liées au tabagisme ont été incluses dans l'analyse. Pour chaque pays, le nombre total de décès par maladie, par âge et par sexe chez les personnes âgées de 15 ans et plus a été obtenu à partir d'une base de données de l'Organisation mondiale de la Santé. L'approche du capital humain a été utilisée pour calculer le coût de la mortalité prématurée.

Résultats : Le tabagisme était responsable de 465285 décès dans les pays de la Région Moyen-Orient et Afrique du Nord, ce qui représente 7122706 années potentielles de vie perdues, soit une moyenne de 15,23 années perdues par décès lié au tabagisme. Sur le nombre total de décès imputables au tabagisme, $412415(88,6 \%)$ sont survenus chez des hommes, soit $37 \%$ de tous les décès dus aux maladies considérées dans cette analyse chez les hommes. Le coût total de la mortalité attribuable au tabagisme a été estimé à 29,7 milliards de dollars des États-Unis d'Amérique (US) en 2015 (0,76\% du produit intérieur brut de la Région Moyen-Orient et Afrique du Nord). La Turquie était le pays le plus touché par l'épidémie de tabagisme, représentant $41 \%$ du coût de la mortalité liée au tabagisme dans l'ensemble de la Région, suivie par l'Arabie saoudite (8,76\%) et l'Égypte $(7,88 \%)$.

Conclusion: Le tabagisme est une cause importante et évitable de mortalité prématurée dans les pays de la Région Moyen-orient et Afrique du Nord. Il est possible de réduire considérablement le nombre de décès imputables au tabagisme et de réaliser d'importantes économies dans cette région grâce à des politiques de lutte antitabac plus efficaces.

$$
\begin{aligned}
& \text { تكلفة الوفيات المبكرة الناجمة عن التدخين في الشرق الأوسط وشمال أفريقيا } \\
& \text { معاذ ناجي، آرثورن ريوبايبون، مونتارات ثافورنشارونساب المبره } \\
& \text { الخلاصة } \\
& \text { الخلفية: يُعد تدخين التبخ أحد الأسباب الرئيسية للوفاة المبكرة، وينجم عن ذلك تكبّد تكاليف اقتصادية كبيرة. } \\
& \text { الأهداف: هدفت هذه الدراسة الى تقدير معدل وتكلفة الوفيات المبكرة الناجمة عن التدخين في } 24 \text { بلدًا في إقليم الشرق الأوسط وشمال أفريقيا في } \\
& \text { عام } 2015 .
\end{aligned}
$$

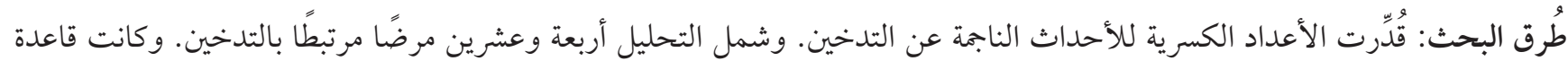

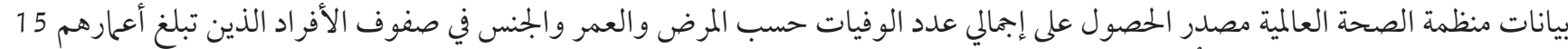

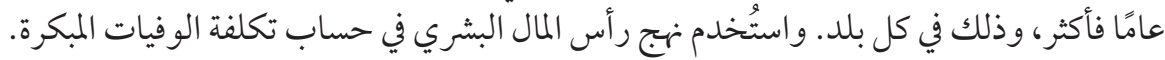

$$
\begin{aligned}
& \text { النتائج: تَسبَّب التدخين في وقوع }
\end{aligned}
$$

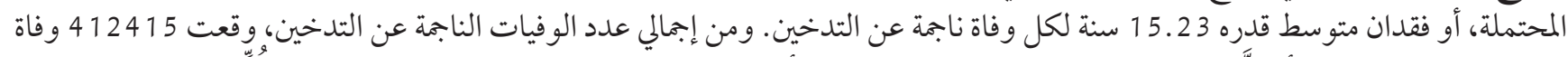

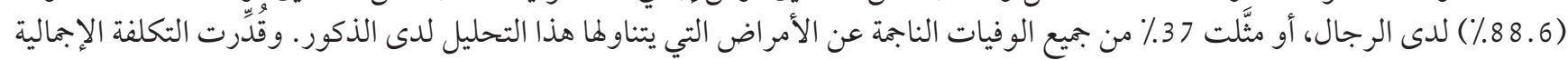

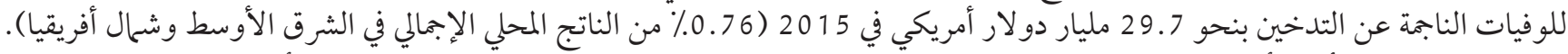

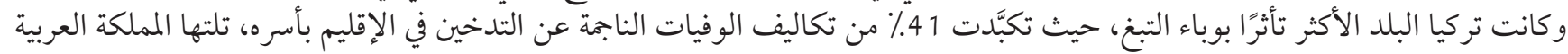

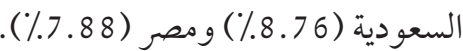

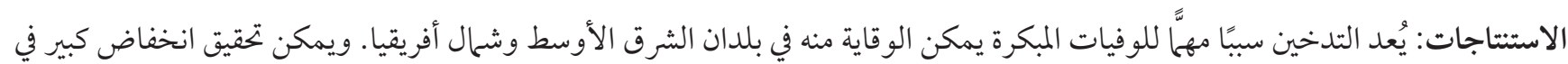

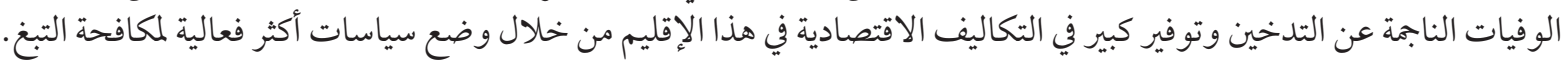




\section{References}

1. The health consequences of smoking-50 years of progress. A report of the Surgeon General. Atlanta: Centers for Disease Control and Prevention; 2014 (https://www.cdc.gov/tobacco/data_statistics/sgr/50th-anniversary/index.htm, accessed 30 April 2021).

2. GBD 2015 Tobacco Collaborators. Smoking prevalence and attributable disease burden in 195 countries and territories, 19902015: a systematic analysis from the Global Burden of Disease Study 2015. Lancet. 2017 May 13;389(10082):1885-906. https://doi. org/10.1016/So140-6736(17)30819-X PMID:28390697

3. Goodchild M, Nargis N, Tursan d'Espaignet E. Global economic cost of smoking-attributable diseases. Tob Control. 2018 Jan;27(1):58-64. https://doi.org/10.1136/tobaccocontrol-2016-053305 PMID:28138063

4. The World Fact Book 2018. Washington, DC: Central Intelligence Agency; 2018 (https://www.cia.gov/the-world-factbook/about/ cover-gallery/2018-cover/, accessed 30 April 2021).

5. Usmanova G, Mokdad AH. Results of the Global Youth Tobacco Survey and implementation of the WHO Framework Convention on Tobacco Control in the WHO Eastern Mediterranean Region (EMR) countries. J Epidemiol Glob Health. 2013 Dec;3(4):217-34. https://doi.org/10.1016/j.jegh.2013.07.001 PMID:24206793

6. Kulhanova I, Bray F, Fadhil I, Al-Zahrani AS, El-Basmy A, Anwar WA, et al. Profile of cancer in the Eastern Mediterranean region: the need for action. Cancer Epidemiol. 2017 Apr;47:125-32. https://doi.org/10.1016/j.canep.2017.01.009 PMID:28268206

7. Rastogi T, Hildesheim A, Sinha R. Opportunities for cancer epidemiology in developing countries. Nat Rev Cancer. 2004 Nov;4(11):909-17. https://doi.org/10.1038/nrc1475 PMID:15516963

8. GBD 2015 Eastern Mediterranean Region Cardiovascular Disease Collaborators. Burden of cardiovascular diseases in the Eastern Mediterranean Region, 1990-2015: findings from the Global Burden of Disease 2015 study. Int J Public Health. 2018 May;63(Suppl 1):S137-49. https://doi.org/10.1007/s00038-017-1012-3 PMID:28776245

9. GBD 2015 Eastern Mediterranean Region Cardiovascular Disease Collaborators. Burden of lower respiratory infections in the Eastern Mediterranean Region between 1990 and 2015: findings from the Global Burden of Disease 2015 study. Int J Public Health. 2018 May;63(Suppl 1):97-108. https://doi.org/10.1007/s00038-017-1007-o PMID:28776246

10. Economics of tobacco toolkit: assessment of the economic costs of smoking. Geneva: World Healtht Organization; 2011 (https:// apps.who.int/iris/handle/10665/44596, accessed 30 April 2021).

11. Middle East and North Africa [website]. World Bank Data; 2021 (https://www.worldbank.org/en/region/mena, accessed 30 April 2021).

12. Seizing the opportunity: ending AIDS in the Middle East and North Africa. Amman: United Nations Children's Fund; 2019 (https://www.unicef.org/mena/reports/seizing-opportunity-ending-aids, accessed 30 April 2021).

13. Waas LV. The situation of stateless persons in the Middle East and North Africa. United Nations High Commissioner for Refugees; 2010. (https://www.unhcr.org/uk/protection/statelessness/4ce63e079/situation-stateless-persons-middle-east-north-africa-laura-van-waas.html, accessed 30 April 2021).

14. Gandini S, Botteri E, Iodice S, Boniol M, Lowenfels AB, Maisonneuve P, et al. Tobacco smoking and cancer: a meta-analysis. Int J Cancer. 2008 Jan 1;122(1):155-64. https://doi.org/10.1002/ijc.23033 PMID:17893872

15. Jayes L, Haslam PL, Gratziou CG, Powell P, Britton J, Vardavas C, et al. SmokeHaz: systematic reviews and meta-analyses of the effects of smoking on respiratory health. Chest. 2016 Jul;150(1):164-79. https://doi.org/10.1016/j.chest.2016.03.060 PMID:27102185

16. Global report on trends in prevalence of tobacco smoking 2015. Geneva: World Health Organization; 2015 (https://apps.who.int/ iris/bitstream/handle/10665/156262/9789241564922_eng.pdf?sequence=1, acccessed 30 April 2021).

17. Report on the global tobacco epidemic 2017. Tobacco Free Initiative. Country-provided prevalence data. Geneva: World Health Organization; 2017 (http://www.who.int/tobacco/global_report/2017/appendix-xi/en/, accessed 30 April 2021).

18. Khattab A, Javaid A, Iraqi G, Alzaabi A, Ben Kheder A, Koniski M-L, et al. Smoking habits in the Middle East and North Africa: results of the BREATHE study. Respir Med. 2012 Dec;106 Suppl 2:S16-24. https://doi.org/10.1016/S0954-6111(12)70011-2 PMID:23290700

19. Prevalence of current tobacco use, males (\% of male adults) - Jordan [website]. World Bank (https://data.worldbank.org/indicator/SH.PRV.SMOK.MA?locations=JO, accessed 30 April 2021).

20. Ng M, Freeman MK, Fleming TD, Robinson M, Dwyer-Lindgren L, Thomson B, et al. Smoking prevalence and cigarette consumption in 187 countries, 1980-2012. JAMA. 2014 Jan 8;311(2):183-92. https://doi.org/10.1001/jama.2013.284692 PMID:24399557

21. Ward KD, Eissenberg T, Rastam S, Asfar T, Mzayek F, Fouad MF, et al. The tobacco epidemic in Syria. Tob Control. 2006 Jun;15 Suppl 1:i24-9. https://doi.org/10.1136/tc.2005.014860 PMID:16723671

22. Forey BA, Thornton AJ, Lee PN. Systematic review with meta-analysis of the epidemiological evidence relating smoking to COPD, chronic bronchitis and emphysema. BMC Pulm Med. 2011 Jun 14;11:36. https://doi.org/10.1186/1471-2466-11-36 PMID:21672193

23. Willi C, Bodenmann P, Ghali WA. Active smoking and the risk of type 2 diabetes: a systematic review and meta-analysis. JAMA Intern Med. 2007 Dec 12;298(22):2654-64. https://doi.org/10.1001/jama.298.22.2654 PMID:18073361

24. Ezzati M, Henley SJ, Thun MJ, Lopez AD. Role of smoking in global and regional cardiovascular mortality. Circulation. 2005 Jul 26;112(4):489-97. https://doi.org/10.1161/CIRCULATIONAHA.104.521708 PMID:16027251 
25. Global health estimates: life expectancy and leading causes of death and disability [website]. Geneva: World Health Organization (http://www.who.int/healthinfo/global_burden_disease/estimates/en/index1.html, accessed 30 April 2021).

26. Global Health Observatory country views [website]. Geneva: World Health Organization (http://apps.who.int/gho/data/node. country, accessed 30 April 2021).

27. World economic outlook database [website]. Washington, DC: International Monetary Fund; 2017 (https://www.imf.org/external/pubs/ft/weo/2017/02/weodata/weoselgr.aspx, accessed 30 April 2021).

28. GDP per capita (current US\$). World Bank national accounts data, and OECD National Accounts data files [website]. Washington, DC: World Bank (https://data.worldbank.org/indicator/NY.GDP.PCAP.CD, accessed 30 April 2021).

29. UN data, a world of information [website]. United Nations (https://data.un.org, accessed 30 April 2021).

30. Ma J, Siegel RL, Jacobs EJ, Jemal A. Smoking-attributable mortality by state in 2014, U.S. Am J Prev Med. 2018 May;54(5):661-70. https://doi.org/10.1016/j.amepre.2018.01.038 PMID:29551325

31. Kristina SA, Endarti D, Thavorncharoensap M. Burden of cancer attributable to tobacco smoking in member countries of the Association of Southeast Asian Nations (ASEAN), 2012. Cancer Epidemiol. 2016 Oct;44:84-90. https://doi.org/10.1016/j. canep.2016.08.005 PMID:27513722

32. WHO global report: mrotality attributable to tobacco. Geneva: World Health Organization; 2012 ( http://www.who.int/tobacco/ publications/surveillance/rep_mortality_attributable/en/, accessed 30 April 2021).

33. Yang L, Sung H-Y, Mao Z, Hu T-w, Rao K. Economic costs attributable to smoking in China: update and an 8-year comparison, 2000-2008. Tob Control. 2011 Jul;20(4):266-72. https://doi.org/10.1136/tc.2010.042028 PMID:21339491

34. Neergaard J, Singh P, Job J, Montgomery S. Waterpipe smoking and nicotine exposure: a review of the current evidence. Nicotine Tob Res. 2007 Oct;9(10):987-94. https://doi.org/10.1080/14622200701591591 PMID:17943617

35. Carter BD, Abnet CC, Feskanich D, Freedman ND, Hartge P, Lewis CE, et al. Smoking and mortality - beyond established causes. N Engl J Med. 2015 May 28;372(7):631-40. https://doi.org/10.1056/NEJMc1503675 PMID:26017837 